\title{
Perceived Impact of Motherhood on Adherence to Therapy in Mothers with Cystic Fibrosis
}

\section{Einfluss der Mutterschaft auf die Therapieadhärenz aus Sicht von Müttern mit Mukoviszidose}

Authors

Institutions
G. Ullrich ${ }^{1}$, I. Bobis ${ }^{2}$, B. Bewig ${ }^{2}$

Private Practice, Schwerin, Germany

${ }^{2}$ Adult CF centre, University Hospital Schleswig-Holstein, Kiel, Germany received 18.6.2015 accepted after revision 5.8.2015

\section{Bibliography}

Dol http://dx.doi.org/ 10.1055/s-0034-1392957

Published online: 23.9 .2015

Pneumologie 2015; 69: 673-679

(c) Georg Thieme Verlag KG

Stuttgart · New York

ISSN 0934-8387

Corresponding author

Dr. Gerald Ullrich

Reutzstr. 1

19055 Schwerin

Ullrich@med-wiss.com

\section{Abstract \\ $\nabla$}

Aim: To explore the stress related to motherhood and its perceived impact on adherence to therapy in women with cystic fibrosis (CF).

Methods: Cross-sectional study with a purposedesigned questionnaire.

Sample: 46/73 eligible women were enrolled and 38 returned the questionnaire. Mean age of mothers was $33.8 \mathrm{y} \pm 7.1 \mathrm{y}$, mean age of firstborn child was $6.9 \mathrm{y} \pm 5.7 \mathrm{y}$. Nine women had more than one biological child. 18 mothers (47\%) were currently employed, 12 of whom worked 19 to 30 hours per week and none full-time.

Results: There were mothers who reported a detrimental effect on adherence (time constraints $38 \%$; intentional nonadherence $42 \%$, and mothers who reported that adherence had actually improved (29\%). Both of these effects were related to daily CF therapy at home. By contrast, i.v. antibiotic therapy was less impaired by role strains, mainly due to home i.v. therapy being an alternative and/or due to intensive social support (husband, parents). Participants clearly addressed the importance of adherence and the need for adequate self-management in narrative comments.

Conclusion: Motherhood may improve adherence to $C F$ therapy as well as it may affect it negatively. Health caregivers are well-advised to address a possible detrimental effect, proactively.

\section{Zusammenfassung \\ $\nabla$}

Ziel: Es sollten bei Müttern mit CF die Auswirkungen der Mutterschaft auf die CF-Therapie aus Sicht dieser Frauen erfasst werden.

Methoden: Querschnittsbefragung mit einem für diese Studie erstellten Fragebogen.

Stichprobe: 46/73 möglichen Frauen willigten zur Studienteilnahme ein, von denen 38 ausgefüllte Fragebögen zurücksandten. Das Durchschnittsalter der Mütter lag bei 33,8 \pm 7,1 Jahren, das Durchschnittsalter des erstgeborenen Kindes war $6,9 \pm 5,7$ Jahre. Neun Frauen hatten mehr als ein Kind geboren. 18 Frauen (47\%) waren zum Zeitpunkt der Befragung berufstätig, davon $12 \mathrm{im}$ Umfang 19-30 Wochenstunden und keine in Vollzeit.

Ergebnisse: Es gab sowohl Mütter, die eine Beeinträchtigung der CF-Therapie durch die Mutterschaft einräumten $(38 \%$ mit Verweis auf Zeitknappheit, $42 \%$ gaben bewusste Reduktion der Therapie an) als auch Mütter, die über eine verbesserte Therapieumsetzung aufgrund der Mutterschaft berichteten (29\%). In beiden Fällen bezogen sich diese Effekte auf die häusliche, tägliche CF-Therapie. Bei der i.v.-antibiotischen Therapie gab es hingegen weniger häufig Einschnitte durch die Mutterschaft zu beklagen, überwiegend dank der Möglichkeit zu häuslicher i.v.-Antibiotikatherapie oder dank intensiver sozialer Unterstützung (Partner, Eltern). Die befragten Frauen brachten in Freitextkommentaren deutlich zum Ausdruck, dass ihnen die Wichtigkeit der Therapieumsetzung und eines adäquaten Selbstmanagements bewusst ist.

Schlussfolgerungen: Mutterschaft kann sich sowohl positiv als auch negativ auf die Therapieumsetzung auswirken. In der CF-Sprechstunde sollten mögliche Beeinträchtigungen der Therapie proaktiv angesprochen werden. 


\section{Introduction}

$\nabla$

$\mathrm{CF}$ is one of the most common, life-shortening genetic diseases affecting young people of Caucasian background. It has a lifelong impact and is a result of abnormal genetic mutations that disturb transportation of salt and water across cell membranes, leading to increased viscosity of mucous and serous secretions. It is a complex, multi-system disorder, with a heterogeneous presentation, a variable rate of progression and peak adverse effects occurring at varying times, mostly starting in childhood [1]. The primary impairments in CF affect respiratory and digestive structures and functions, but also fertility. In males, infertility is almost certain, [2] while females are considered fertile but pregnancy may become a health risk to the women (and to the unborn child) [2-4]. However, women in stable health and wishing to become pregnant, today are encouraged to do so $[2,5]$.

As people with $\mathrm{CF}$ are healthier than ever before when they enter adult life, [6] parenthood is now becoming a real option [5,7]. One of the workshops at the 2013 European Cystic Fibrosis Conference in Lisbon, Portugal, was even entitled "The pregnancy epidemic" [8]. However, CF research almost completely missed the important topic of parenthood. Apart from two recent papers also resulting from our study, $[9,10]$ there is so far not a single full paper that has addressed non-medical, psychosocial aspects of motherhood in cystic fibrosis, i.e. the life experience of people with $\mathrm{CF}$ becoming parents.

Remarkably, even though psychosocial data of motherhood in $\mathrm{CF}$ have not yet been addressed, adherence to therapy has been mentioned, early on. Though not substantiated by empirical data, an impact was assumed in both directions, namely that adherence would decrease $[5,11]$ or improve [5]. Improvement of adherence may be thought of as resulting from substantially higher motivation to maintain stable health in order to see the child grow. Incomplete adherence, however, may be thought of as resulting from overload (i.e. competing demands of therapy, household, and motherhood) in combination with an assumed female attitude that "the child comes first".

The lack of empirical data on the life experience of parents (mothers) with CF is a major drawback particularly for health care providers. They are expected to go beyond the medical pros and cons of pregnancy in $\mathrm{CF}$, and to also discuss the more complex aspects of parenthood $[2,12,13]$. However, as long as respective data are lacking, this extended counselling will likely be omitted or it will be based on ad hoc cases the professional eventually becomes aware of.

Therefore, we performed a multi-method study on the life experience of mothers with $\mathrm{CF}$ and focus in this paper on the women's perception of the impact of motherhood on adherence to CF therapy.

\section{Methods}

$\nabla$

The present part of the study is based on data assessed with a purpose-designed questionnaire that was pilot tested in advance, but has not been tested psychometrically.

The questionnaire aimed to inquire about CF specific aspects of motherhood (see appendix). Most parts of the questionnaire focussed on the impact of CF on motherhood, while some items also assessed the impact of motherhood on adherence to therapy, namely adherence to daily home-based regimen and to i.v. antibiotic treatment.

\section{Measures}

The first items of the questionnaire asked about an impact of pregnancy and motherhood on lung function and on other aspects of health, respectively (items 1.1 and 1.2, for original wording and numbering of items see appendix). Any impact had to be qualified in narrative comments. These were then rated (by $\mathrm{GU})$ as either positive or negative health impacts.

The overall impact of motherhood on CF therapy was assessed with a number of multiple-choice questions:

a) impact on adherence to daily CF treatment (1.3), particularly the number of respondents who responded with: "Due to time constraints, I regularly quit parts of my treatments";

b) impact on adherence to i.v. antibiotic treatment (1.4), particularly the number of respondents who responded with:

"I refuse hospital treatment as long as ever possible".

We also explicitly addressed possible overload resulting from time-consuming CF treatment and the duties as a mother (4.1.8; $4.2 .1 ; 4.3 .2 ; 4.4 .2)$. These multiple-choice questions inquired about the impact on adherence to daily CF treatment at different age periods of the child (baby period, toddler stage, preschool and kindergarten, school-aged children). A negative impact of motherhood on adherence was assumed, if respondents chose the response option "For lack of time, I couldn't adequately perform my therapies" or "To manage the multitude of my tasks, I had to cut down my therapies to the bar necessities". Unlike the item about an overall impact on adherence, these multiplechoice questions did not offer a response option addressing a possible positive impact of motherhood on adherence.

Finally, we also checked whether adherence issues were addressed in fill-in-the-gap items (7.1 to 7.5). Respondents were asked to write three of the most important conclusions they could draw from their experience as a mother with CF. These suggestions had to be addressed to three possible recipients: a) a women with $\mathrm{CF}$ (and relating to her wish to become pregnant, to the pregnancy, and to being a mother with $\mathrm{CF}$ ), b) to the partner of such a women, c) to a CF-team looking after mothers with CF (see also appendix, section 7).

\section{Data analysis}

Given the explorative character of our study, simple frequency distributions and descriptive comparison were calculated for multiple-choice items. Answers to fill-in-the-gap items were content analysed and categorised (by GU). In order to assess inter-rater reliability, coding of write-in responses along these categories were then performed, in parallel (by GU and IB). Possible discordance was discussed and consensually resolved. Concordance of original ratings was calculated according to Cohen's Kappa [14]. For the five fill-in-the-gap items, concordance values (kappa) were satisfactorily high $(\mathrm{k}=.56$ to $.81 ;<0.001)$, which means that concordance ranged from $66 \%$ to $86 \%$ (with concordance by chance ranging from $15 \%$ to $23 \%$ ).

All other statistical analyses, namely t-tests to compare means and non-parametrical tests to compare frequencies, were performed with GraphPad Prism 6.01 (GraphPad Software, Inc., La Jolla, CA). 
Table 1 Demographic aspects of the sample $(\mathrm{N}=38)$.

\begin{tabular}{|lc|}
\hline Age of the mother (years; mean \pm SD) & $33.8 \pm 7.1$ \\
\hline Age of firstborn child (years; mean \pm SD) & $6.9 \pm 5.7$ \\
\hline Age of child (categories) & $11 / 38(29 \%)$ \\
\hline - Toddlers (<3 years) & $10 / 38(26 \%)$ \\
\hline - Preschool and Kindergarten (3 y to 5 y) & $5 / 38(13 \%)$ \\
\hline - Primary school (6y to 9y) & $7 / 38(18 \%)$ \\
\hline - Grades 5 to 6 (10y to 13y) & $3 / 38(8 \%)$ \\
\hline - Adolescents (14y to 17y) & $2 / 38(5 \%)$ \\
\hline - Adults & $21: 17(55 \% / 45 \%)$ \\
\hline Child's sex (Female/Male $\%)$ & \\
\hline Number of biological children & $29 / 38(76 \%)$ \\
\hline - one & $6 / 38(16 \%)$ \\
\hline - two & $3 / 38(8 \%)$ \\
\hline - three & $32 / 38(84 \%)$ \\
\hline Married or equivalent & $18 / 38(47 \%)$ \\
\hline At least part-time employment (i. e. mother & \\
\hline with own salary at the time of the study) & \\
\hline
\end{tabular}

\begin{tabular}{|c|c|}
\hline Mother's age at CF diagnosis & \\
\hline - at birth/within first two years of life & $27 / 38(71 \%)$ \\
\hline - up to $12 y$ & $5 / 38(13 \%)$ \\
\hline - during adolescence & $2 / 38(5 \%)$ \\
\hline - as an adult & $4 / 38(11 \%)$ \\
\hline $\begin{array}{l}\text { Current Body Mass Index }\left[\mathrm{BMI}, \mathrm{kg} / \mathrm{m}^{2}\right] \\
\text { (mean } \pm \mathrm{SD} \text {; range) }\end{array}$ & $\begin{array}{l}20.8 \pm 2.5 \\
16.2-28.3\end{array}$ \\
\hline$-\mathrm{BMI}<18 \mathrm{~kg} / \mathrm{m}^{2}$ & $5 / 37(14 \%)$ \\
\hline Current FEV1 in Perc. pred. (mean \pm SD) & $66 \pm 19(n=29)^{1}$ \\
\hline - FEV1 in Perc. pred. $<50 \%$ & $3 / 29(10 \%)$ \\
\hline CF-related diabetes at present & $15 / 38(39 \%)$ \\
\hline $\begin{array}{l}\text { Treatment with pancreatic enzymes prior to } \\
\text { pregnancy }\end{array}$ & $30 / 38(79 \%)$ \\
\hline Chronic infection with Pseudomonas aeruginosa & $33 / 38(87 \%)$ \\
\hline \multicolumn{2}{|l|}{$\begin{array}{l}\text { Amount of time (minutes) devoted every day to CF } \\
\text { therapies (i.e. including physiotherapy and sports) }\end{array}$} \\
\hline - prior to first pregnancy (mean $\pm S D ;$ median) & $89 \pm 59(n=34)$ \\
\hline - at present (mean $\pm S D$; median) & $90 \pm 59(n=36)$ \\
\hline
\end{tabular}

${ }^{1}$ Reduced sample size due to missing data or mother unaware of lung function.

\section{Procedure}

The study protocol was approved by the Institutional Review Board at the University Hospital Kiel, Germany.

We announced our study to all German CF centres by means of a nationwide mailing list covering about $200 \mathrm{CF}$ doctors, and asked for their support. CF centres that were willing to cooperate disclosed the number of eligible women. Inclusion criteria were (1) mother's literal and cognitive competence, and her command of language were considered sufficient to understand and respond to the questionnaires, (2) her firstborn child was at least $1 \mathrm{y}$ and younger than $13 \mathrm{y}$. The child's age range was drawn with respect to another research tool [15]. Its reference values range from parents of children aged 1 to 12 years. Results of this assessment are reported elsewhere [10].

We then sent invitation letters for each mother to the respective CF centre where staff forwarded our letter to the mother's address. If the respective mother was willing to participate, she filled in the informed consent and a short demographic sheet and returned it in a prepaid envelope to the study centre. We then mailed the set of study questionnaires directly to each participant together with a postage-paid return envelope.

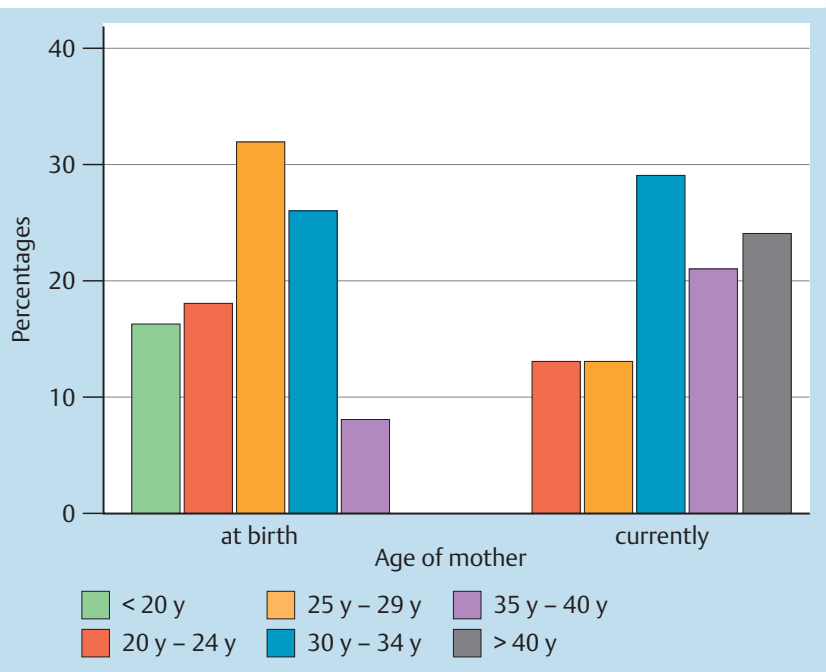

Fig. 1 Age distribution of $\mathrm{n}=38$ participants at birth of the first child and at the time of the study.

During the recruitment stage, CF centres had also informed mothers of older children who then signed in. Given the explorative character of our study, we decided not to exclude these mothers.

\section{Sample \\ $\nabla$}

19 CF centres forwarded our invitation letter to 72 mothers with CF. Of these, 43 mothers who were treated in $16 \mathrm{CF}$ centres signed in. However, some women withdrew their consent when they received the questionnaires because it appeared too time-consuming or was too private in nature. Therefore, the true number of participants was $37 / 43(86 \%)$ or $37 / 72(51 \%)$, respectively. Since the pilot draft of our questionnaire hardly differed from the final version, we also included the mother who answered to the pilot draft, resulting in a sample of 38 out of 73 participants.

Health-related and socio-demographic aspects of the study sample are summarised in $\bullet$ Tab. 1 and $\bullet$ Tab.2.

At the time of the study, participants were on average $33.8 \mathrm{y} \pm 7.1 \mathrm{y}$ old $(21 y-46 y)$. At the time of their first delivery, the majority of mothers were in their twenties, 6 mothers were younger than 20 years, the youngest being $15.7 \mathrm{y}$ old (see $\odot$ Fig. 1 ).

Most of the participants (76\%) had given birth to one child, six women had two biological children and three women had three children.

The firstborn child's age was on average $6.9 \mathrm{y} \pm 5.7 \mathrm{y}$. Given the inclusion criteria, the largest groups were mothers of younger children (29\% infants and toddlers, $26 \%$ pre-school and kindergarten).

Only 29/38 participants reported their current Forced Expiratory Volume in 1 second (FEV1) in percent predicted, which was $66 \pm$ $19 \%$ on average, with 17 participants (59\%) having a FEV1 of less than $70 \%$ (minimum $20 \%$ ). None of the woman had a lung transplant.

To our knowledge, conception was normal in all but two women. CF was diagnosed late, namely during adolescence or even later, in six participants (16\%), one of whom was diagnosed shortly after giving birth to her third child.

At the time of their first delivery, eight women (21\%) did not perform enzyme replacement therapy, two of whom had not yet been diagnosed CF. The percentage of women with pancreas suf- 
ficiency (and a likely milder course of the disease) [15] is therefore $16 \%(6 / 38)$ to $21 \%(8 / 38)$, which compares to the expected frequency (18\%) for adult CF patients in Germany [16].

18 mothers (47\%) were currently employed, 12 of whom worked 19 to 30 hours per week and none full-time. Three couples divorced right from the start of parenthood (8\%) or shortly after (8\%). Partnership was stable in $84 \%$ of participants.

\section{Results}

$\nabla$

The first two items of the questionnaire asked about a lasting impact of pregnancy or motherhood on health (see items 1.1 und 1.2 in appendix). One question addressed lung function and almost three in four respondents (71\%) denied any impact on lung function, $3 \%$ stated a positive impact and $26 \%$ a negative. The second question asked about other health related effects of motherhood. No such impact was mentioned by $68 \%$ of respondents, while $14 \%$ mentioned a positive impact and described it in narrative comments (e.g. "more stable health since you are much more active as a mother of a child"). A negative impact was mentioned and described by $19 \%$ of respondents (e.g. "numerous dates with the child prevented me from fully treating my exacerbations").

- Tab. 3 concurrently shows the results regarding the responses given to both items. The largest group were women who neither perceived an impact on lung function nor another health related impact. When comparing women who said that their health was stable or improved $(n=23)$ with women who noticed at least one kind of deterioration $(n=15)$ there were no differences in terms

Table 3 Cross table of perceived impact of pregnancy and motherood on lung function and other aspects of health (raw figures).

\begin{tabular}{|llcl|}
\hline & \multicolumn{2}{l}{ Lung function } & \\
\hline Other health aspects & Improved & Unchanged & Worse \\
\hline Improved & 0 & 4 & 1 \\
\hline Unchanged & 1 & 18 & 7 \\
\hline Worse & 0 & 5 & 2 \\
\hline
\end{tabular}

of time devoted to daily CF treatment (both at the time of delivery and at the time of the study; $\mathrm{p}=0.5$ and 0.9 , respectively). The general impact of motherhood on CF therapy (item 1.3) was characterised in terms of 'controlled' (intentional) nonadherence by $42 \%$ of respondents, which means that they regularly skipped parts of their therapy.

A slightly fewer percentage (37\%) complained about a "lack of time" for doing their treatments, and $29 \%$ stated that adherence to therapy had actually improved. Although the question was multiple-choice, only four respondents ticked more than one option (so that "lack of time for therapy" and "cutting down therapy" obviously address different aspects or qualities). Narrative comments to this question revealed, that cutting down of therapy (intentional partial nonadherence) mostly meant to skip exercise $(5 \times)$ or physiotherapy $(5 x)$. However, the reported time devoted to daily CF therapy (at the time of first delivery; at the time of the study) did not differ significantly between these groups (and between the time points; see $\bullet$ Tab.4).

With regard to i.v. antibiotic treatment (item 1.4), intentional nonadherence seemed less of a problem: the majority had chosen home i.v. therapy (74\%) as an alternative to hospital i. v. courses and/or was able to procure social support from their husbands (39\%) or parents/parents-in-law (47\%) in order to combine i.v. courses and look after the child. However, $24 \%$ of respondents also admitted they had denied hospital therapy as a long as ever possible, so reduced the reasonable number of i.v. courses and performed less than optimal CF therapy. Women who perceived at least one deterioration (lung function and or other aspects of health) more often admitted to deny therapy (50\%) compared to those who were stable or perceived improvement (21\%), although this difference failed to be statistically significant $(\mathrm{p}=0.44)$.

As for the items that differentiate problems with adherence according to the child's age $(4.1 .8 ; 4.2 .1 ; 4.3 .2 ; 4.4 .2)$, the total number of respondents has to be kept in mind.

The respective items explicitly addressed the delicate balance of competing tasks as a mother with $\mathrm{CF}$, and among a number of response options those that admitted a negative impact on adherence are displayed in $\bullet$ Tab. 5 .

\begin{tabular}{|c|c|c|}
\hline \multirow{2}{*}{$\begin{array}{l}\text { Perceived impact of motherhood on adherence } \\
\text { to CF therapy }\end{array}$} & \multicolumn{2}{|c|}{ Time for therapy ( $\mathrm{M} \pm \mathrm{SD}$ in min.) } \\
\hline & at the time of delivery ${ }^{1}$ & at the time of the study ${ }^{1}$ \\
\hline Suboptimal performance of CF therapy due to lack of time & $83 \pm 72(n=14)$ & $85 \pm 65(n=14)$ \\
\hline Intentional partial non-adherence & $56 \pm 41(n=16)$ & $79 \pm 57(n=15)$ \\
\hline Adherence to therapy improved & $79 \pm 59(n=11)$ & $109 \pm 66(n=10)^{2}$ \\
\hline
\end{tabular}

Table 4 Perceived adherence and time devoted to CF therapy.

${ }^{1}$ Analysis of variance (one-way) not statistically significant ( $p=0.4$ and 0.49 , respectively).

2 Pre to post comparison (t-test) not significant $(p=0.29)$.

\begin{tabular}{|c|c|c|c|c|}
\hline \multirow[t]{2}{*}{ Mothers' problems with CF therapy' } & \multicolumn{4}{|c|}{ Motherhood at different age periods of the child } \\
\hline & $\begin{array}{l}\text { Baby } \\
(n=38)\end{array}$ & $\begin{array}{l}\text { Toddler } \\
(\mathrm{n}=33)\end{array}$ & $\begin{array}{l}\text { Preschool/Kindergarten } \\
(n=18)\end{array}$ & $\begin{array}{l}\text { School-age } \\
(n=14)\end{array}$ \\
\hline $\begin{array}{l}\text { Lack of time to adequately perform } \\
\text { CF therapy }\end{array}$ & $39 \%$ & $27 \%$ & $33 \%$ & $14 \%$ \\
\hline IV courses refused as long as possible & $6 \%$ & $6 \%$ & $6 \%$ & $7 \%$ \\
\hline $\begin{array}{l}\text { No particluar problems, as long as no } \\
\text { lung infection }\end{array}$ & $58 \%$ & $61 \%$ & $56 \%$ & $71 \%$ \\
\hline
\end{tabular}

Table 5 Adherence problems during different periods of motherhood. 
Table 6 Suggestions of participants to women with CF (raw figures).

\begin{tabular}{|c|c|c|}
\hline Content & First $^{1}$ & Other $^{1}$ \\
\hline \multicolumn{3}{|l|}{ Suggestions to women facing pregnancy } \\
\hline - Pay attention to optimal CF and obstetrical care & 9 & 7 \\
\hline $\begin{array}{l}\text { - Adherence to CF therapy, optimizing health } \\
\text { status }\end{array}$ & 7 & 7 \\
\hline - Keep calm and be mindful of yourself & 7 & 5 \\
\hline $\begin{array}{l}\text { - Look for relief of the strain (e. g. support from } \\
\text { family; skip job early; accept support) }\end{array}$ & 5 & 6 \\
\hline - Other suggestions & 2 & 2 \\
\hline \multicolumn{3}{|l|}{ Suggestions to women facing motherhood } \\
\hline - Look for relief of the strain and be mindful of yourself & 11 & 8 \\
\hline - Do not disregard CF therapy/your health status & 11 & 6 \\
\hline - Mainly encouraging comments & 5 & 3 \\
\hline - Other suggestions & 4 & 9 \\
\hline
\end{tabular}

${ }^{1}$ Respective suggestion was mentioned first (first) or at the second/third place (other).

Some narrative comments to these items suggested that coping becomes easier as the child grows older, but distribution of respective frequencies was normal.

With respect to the questions that asked mothers to draw conclusions from their experience in terms of giving suggestions to concerned people (items 7.1 to 7.5), health-related issues including adherence to therapy were prominently addressed in suggestions referring to other women (but not suggestions to partners, 7.4, or CF teams 7.5). More precisely, respective suggestions were given when referring to "pregnancy and CF" (7.2) and "being a mother with CF" (7.3) as $\bullet$ Tab. 6 shows.

The predominant theme was that mothers should attend to their own needs, that they need not feel guilty for putting their own needs above their children's, and that staying healthy was part of a responsible parenthood.

\section{Discussion}

$\nabla$

We performed an exploratory study on the perceived impact of motherhood on adherence in adult women with $\mathrm{CF}(\mathrm{n}=38)$ who mostly gave birth to one child. Mean age of the firstborn child was $6.9 \mathrm{y} \pm 5.7 \mathrm{y}$.

In line with clinical experience, responses to the multiple-choice items showed both a detrimental effect of motherhood on adherence (due to time constraints $38 \%$ or intentional partial nonadherence $42 \%$ ), and that adherence to therapy had actually improved (29\%). Both of these effects were related to home-based, daily CF therapy.

By contrast, i.v. antibiotic therapy seemed to be somewhat less impaired by role strains. This was mainly due to home i.v. therapy being an alternative and/or to intensive social support (husbands, parents).

Even though suboptimal daily treatment was mentioned frequently, mothers with CF were well aware about the importance of adherence. In particular, adherence issues were among the key aspects these mothers suggested in narrative comments to concerned other women with CF. Some of these comments explicitly stressed that focussing on good self-management and responsible self-care must not be interpreted as "selfishness", i.e. putting the child's needs beyond their own.
There is so far no published paper on the life experience of mothers with CF and the possible impact of motherhood on adherence to time consuming CF therapy, in particular. However, the issue of adherence has been addressed in several papers or rather unpublished studies:

Based on clinical experience rather than facts, a possible bidirectional effect of motherhood on adherence was assumed. A detrimental effect might likely be the result of role strain [11], as has also been anticipated by British women with CF wanting to become pregnant, which were interviewed by Simcox et al. [16]. An improvement of adherence might be expected as a result of feeling responsible for the child/fulfilling life goals, which explicitly has been mentioned in another study focussing on the life experience of mothers with CF [17]. The results of our study are in line with the expectation of bidirectional effects since both of these were self-reported by the participants.

Unlike mothers interviewed by Cammidge [17] who stated a detrimental effect on adherence only for the first three months after birth (followed by a period with consistently improved adherence), mothers in our study admitted to cutting down therapy well beyond this period. Remarkably, with respect to self-reported time devoted to therapy (either at the time of delivery or at the time of the study) there was no statistically significant difference between mothers who complained about insufficient time for therapy, or those who have intentionally cut down on CF therapy in order to do their daily chores, or mothers who mentioned improved adherence as a consequence of motherhood. The lack of statistical significance may, however, be the result of large variation and small sample sizes (see Tab.4). Mothers who improved adherence increased the amount of time for therapy between these two time points, though again not statistically significant.

Another (unpublished) study from Belgium also explicitly addressed adherence issues [18]. They interviewed both mothers $(n=10)$ and fathers $(n=8)$ with CF with respect to their life experience including adherence to therapy. Remarkably, according to these authors there appeared to be a gender effect on adherence, namely that mothers with CF would put the child's needs above their own, while fathers with CF would argue that their CF therapy comes first in order to maintain a sufficiently good health. Our study both confirms and denies these results. Mothers in our study, to a large extent, actually admitted that their daily CF therapy was impaired by their motherhood, either in terms of not having enough time to adequately perform therapy or in terms of systematically cutting down on their daily regime. Both of these ways are in line with "putting the child first" as mentioned by the Belgian authors. However, with respect to the conclusions mothers in our study drew from their personal experience and what they suggested to other concerned women was that our results contradict the ones from Belgium. Many women in our study explicitly argued in much the same way as the Belgium group found typical for fathers, namely not to let their self-care become a subordinate issue.

Finally, the most comprehensive study about issues of adherence in mothers with CF highlighted the positive effect of motherhood on adherence [17]. This is confirmed by our study where a third of mothers reported better adherence to therapy due to a sense of fulfilling life goals. The latter must not be underestimated as a fundamental source of energy and as a counter balance to the demoralising character of $\mathrm{CF}$ that had already been addressed in the early years of psychosocial CF research [19]. Remarkably, all of the women with $\mathrm{CF}$, in a small case study on "surviving against 
the odds" [20], were mothers (although this paper did not highlight this and referred to "sense of coherence" [21] rather than to fulfilling life goals). Also, a recent study on health-related hindrance of goal pursuit clearly showed the importance of life goals for emotional well-being [22]. Of course, motherhood/parenthood are on top of the list of life goals, at least for many people, and Götz \& Götz [7] once speculated about the possible health effect of fulfilling important life goals in adults with CF. Certainly, this matter deserves to be studied in more depth.

Our study has several limitations. First, although our study is the largest on mothers with CF, the sample size still is rather small, particularly with respect to statistical analyses (power). Second, all data were self-reported. This is a problem particularly with respect to time for therapy, since it tends to be grossly over-estimated (over-reported) [23,24].

Third, we used a convenience sample and women with discouraging experience of motherhood might have avoided enrolment. However, we clearly advised cooperating CF centres not to select candidates but to forward our invitation letter to all mothers with $\mathrm{CF}$ that fulfilled the inclusion criteria. Of note, this sample covers a large range of $\mathrm{CF}$ health, including mothers with almost normal lung function and those with moderate to low lung function, already at the time of pregnancy. In the absence of representative data about the health status of mothers with CF in Germany, we may only speculate whether or not this convenience sample is representative or not.

Despite these limitations, our study shows that adherence issues in mothers with CF are important both from a scientific and clinical point of view.

We already mentioned two aspects that deserve to be studied in more detail: the positive impact of motherhood on adherence, in particular the role of fulfilling life goals on self-management and self-care, and whether or not parenthood and adherence are managed differently, according to gender (mothers compared to fathers with $\mathrm{CF}$ ).

From a clinical point of view, our study underscores that motherhood should be discussed during CF clinics not only at the decisional stage but particularly when the baby is born. Anticipating a negative impact of motherhood on adherence, and time consuming physiotherapy in particular, Edenborough et al. [5] recommend that the importance of adherence should be emphasized at clinic visits. However, as our study shows, a slightly different approach might be worthwhile: Although many mothers with CF tend to practice their daily CF therapy less than optimal, the majority are well aware of its importance. Therefore the focus of counselling should perhaps be on practical issues and on obstacles to adherence rather than on importance. In order to enhance an open rapport, these topics should be addressed proactively and in a non-judgemental way, so indicating an interest of the health practitioner in the practical dilemmas of these women, and to avoid defensiveness on their part.

\section{Acknowledgements}

$\nabla$

This study was supported in total by Novartis Pharma GmbH, Germany.

We also appreciate the support from following colleagues: CF nurse specialist Kerscher and PD Dr. Fischer (Munich), Dipl. Soz.Päd. Becker (Essen), Dr. Sauer-Heilborn (Hanover), Prof. Bargon (Frankfurt/Main), PD Dr. Kappler (Munich), Dr. Dieninghoff (Co- logne), Dr. Hammermann (Dresden), Dr. Heyder (Stuttgart), Dr. Mainz (Jena), PD Dr. Mellies (Essen), Dr. Nährlich (Gießen), Dr. Köster (Oldenburg) Dr. Claßen (Bremen), Dr. Kinder (Neubrandenburg), Prof. Skopnik (Worms), Prof. Hebestreit (Würzburg), Dr. Breuel (Rostock), Dr. Heuer (Hamburg), Dr. Smaczny (Frankfurt/Main), Dr. Vogl-Vosswinkel (Munich), Dr. Rietschel (Cologne), Dr. Wiebel/Dr. Pömpeler (Heidelberg), Dr. Büsing (Osnabrück), Prof. Ballmann (Bochum), PD Dr. Grüber (Frankfurt/Oder).

\section{Declaration of interest}

Dr. Bobis and Prof. Bewig wish to confirm that there are no known conflicts of interest associated with this publication and there has been no significant financial support for this work that could have influenced its outcome.

Dr. Ullrich declares to have been paid for substantial parts of the research the results of which are described in this paper. Research funding was from Novartis Pharma GmbH, Germany. The same company also paid him for medical writing activities and for workshops on "health beliefs and adherence" that Dr. Ullrich held for CF physiotherapists.

\section{References}

1 Hodson ME, Geddes D, Bush A. Cystic fibrosis. London: Arnold Publ; 2007

2 Sawyer SM. Sexual and reproductive health. In: Hodson M, Geddes D, Bush A (Hrsg) Cystic Fibrosis. London: Arnold Publ; 2007: 279-290

3 Edenborough FP. Women with cystic fibrosis and their potential for reproduction. Thorax 2001; 56: 649-655

4 Wexler ID, Johannesson M, Edenborough FP et al. Pregnancy and chronic progressive pulmonary disease. Am J Respir Crit Care Med 2007; 175: $300-305$

5 Edenborough FP, Borgo G, Knoop C et al. Guidelines for the management of pregnancy in women with cystic fibrosis. J Cyst Fibros 2008; 7: s2 s32

6 Hardt Hvon der, Schwarz C, Ullrich G. [Adults with cystic fibrosis. It's not just about longevity] Erwachsene mit Mukoviszidose. Es geht um mehr als die Lebensdauer. Bundesgesundheitsblatt Gesundheitsforschung Gesundheitsschutz 2012; 55: 558-567

7 Götz I, Götz M. Reproduction and parenting. In: Bluebond-Langner M, Lask B, Angst DB (Hrsg). Psychosocial aspects of cystic fibrosis. London: Arnold; 2001: 172 - 187

8 Anonymous. Abstracts of the 36th European Cystic Fibrosis Conference. Lisbon, Portugal, 12-15 June 2013. Journal of cystic fibrosis 2013; 12 (Suppl. 01): s36

9 Ullrich G, Bobis I, Bewig B. [Mothers with cystic fibrosis: psychosocial data about an almost unknown group] Mütter mit Mukoviszidose: Ergebnisse einer Befragung an einer nahezu unbekannten Patientengruppe. Pneumologie 2015; 69: 212-217

10 Ullrich G, Bobis I, Bewig B. Parenting stress in mothers with cystic fibrosis. Disabil Rehabil (In press)

11 Conway SP, Allenby K, Pond MN. Patient and parental attitudes toward genetic screening and its implications at an adult cystic fibrosis centre. Clin Genet 1994; 45: 308-312

12 Tsang A, Moriarty C, Towns S. Contraception, communication and counseling for sexuality and reproductive health in adolescents and young adults with CF. Paediatr Respir Rev 2010; 11: $84-89$

13 Simcox AM, Duff AJ, Morton AM et al. Decision making about reproduction and pregnancy by women with cystic fibrosis. Br J Hosp Med 2009; 70: 639-643

14 Bortz J, Lienert GA. [Brief outline of statistics for clinical research. A practical guide for the analysis of small samples] Kurzgefaßte Statistik für die klinische Forschung. Ein praktischer Leitfaden für die Analyse kleiner Stichproben. Heidelberg: Springer; 1998

15 Domsch H, Lohaus A. [Parents in Stress Questionnaire: Manual] Elternstressfragebogen (ESF): Manual. Göttingen: Hogrefe; 2010

16 Simcox AM, Hewison J, Duff AJ et al. Decision-making about pregnancy for women with cystic fibrosis. Br J Health Psychol 2009; 14: 323-342 
17 Cammidge SL. When women with cystic fibrosis become mothers: Psychosocial impact and adjustment. University of Leeds, School of Medicine, Academic Unit of Psychiatry and Behavioural Sciences 2013

18 Colpaert K, Havermans T. CF and parenting (presented at the 32nd European CF Conference, Brest, 10.6.-13.6.2009). Slides online available (8.8.2013) 2009. http://www.ecfs.eu/projects/internationalnurse-specialist-group-cf/presentations

19 Waddell $C$. The process of neutralisation and the uncertainties of cystic fibrosis. Sociol Health \& Illness 1982; 4: 210-221

20 Johannesson M, Lask B. Survival against the odds. J Cyst Fibros 2003; 2: $46-48$
21 Antonovsky A. [Unravelling the mystery of health - How people manage stress and stay well; 1987] Salutogenese: Zur Entmystifizierung der Gesundheit. Tübingen: dgvt Verlag; 1997

22 Schwartz LA, Drotar D. Health-related hindrance of personal goal pursuit and well-being of young adults with cystic fibrosis, pediatric cancer survivors, and peers without a history of chronic illness. J Pediatr Psychol 2009; 34: 954-965

23 Daniels T, Goodacre L, Sutton C et al. Accurate assessment of adherence: self-report and clinician report vs electronic monitoring of nebulizers. Chest 2011; 140: 425-432

24 Voils CI, Hoyle RH, Thorpe CT et al. Improving the measurement of selfreported medication nonadherence. J Clin Epidemiol 2011; 64: 250 254 